\title{
Electrospray Mass Spectrometry for the Direct Accurate Mass Measurement of Ligands in Complex With the Retinoid X Receptor $\alpha$ Ligand Binding Domain
}

\author{
Johan Lengqvist*, Gunvor Alvélius, Hans Jörnvall, and Jan Sjövall \\ Department of Medical Biochemistry and Biophysics, Karolinska Institutet, Stockholm, Sweden
}

\author{
Thomas Perlmann \\ Ludwig Institute for Cancer Research, Karolinska Institutet, Stockholm, Sweden \\ William J. Griffiths ${ }^{+}$ \\ Department of Pharmaceutical and Biological Chemistry, The School of Pharmacy, University of London, \\ Brunswick Square, London, UK
}

\begin{abstract}
Accurate mass measurements are often used in the structural determination of unknown compounds of low molecular mass (i.e., below $\sim 500 \mathrm{Da}$ ). Recently, it has been shown that accurate mass measurements also can be made on small denatured proteins (i.e., $M_{\mathrm{r}}, \sim 17,000$ ) to confirm their amino acid composition and identify the presence of isoforms. In the current report, we present nondenaturing electrospray (ES) mass spectrometry data on the direct accurate mass measurement of ligands in complex with the retinoid $\mathrm{X}$ receptor ligand binding domain (RXR LBD; $M_{\mathrm{r}}$ 31,370.92). Average mass errors were below $0.198 \mathrm{Da}$, $6.3 \mathrm{ppm}$ (standard deviation [SD], $0.146 ; n=10$ ) for low-affinity fatty acid agonists analyzed in complex with the RXR LBD. Protein consumption was less than $15 \mathrm{pmol}$, with fatty acid ligands present at concentrations corresponding to their median effective concentration value (low micromolar, determined in transfection assays). Although determination of fatty acid mass was only sufficiently accurate to give nominal mass values, measurements were of sufficient accuracy to assign fatty acid chain length, degree of unsaturation, or cyclization. Using $17 \beta$-estradiol as a control, the ability to observe specific ligand binding is shown for both high- and low-affinity $\mathrm{RXR} \alpha$ agonists. In addition, binding of a novel synthetic receptor agonist XCT0315908 to the $\mathrm{RXR} \alpha \mathrm{LBD}$ is reported. This compound showed a high degree of complex formation, and the receptor-ligand complex could be mass measured with an average mass error of $-0.024 \mathrm{Da}$, $0.8 \mathrm{ppm}(\mathrm{SD}, 0.092 ; n=9)$. Thus, specific binding of both nanomolar and micromolar affinity ligands to a nuclear receptor LBD can be directly observed using nondenaturing ES mass spectrometry and accurate mass measurements additionally can be made on intact complexes in the same experiment. This methodology also is applicable when ligands are present as components of mixtures. (J Am Soc Mass Spectrom 2005, 16, 1631-1640) (c) 2005 American Society for Mass Spectrometry
\end{abstract}

$\mathrm{T}$ he value of accurate mass measurements has been known to the mass spectrometry community for $\sim 50 \mathrm{y}[1]$. For masses below $\sim 500 \mathrm{Da}$, the number of unique elemental compositions correspond-

Published online August 8, 2005

Address reprint requests to William J. Griffiths, Department of Pharmaceutical and Biological Chemistry, The School of Pharmacy, University of London, 29-39 Brunswick Square, London WC1N 1AX, UK. E-mail: william.griffiths@ulsop.ac.uk

* Also at the Ludwig Institute for Cancer Research, Karolinska Institutet, Stockholm, Sweden.

† Also at the Department of Medical Biochemistry and Biophysics, Karolinska Institutet, Stockholm, Sweden.

This work was presented in part at the 50th ASMS Conference on Mass Spectrometry and Allied Topics, in Orlando, FL, June 2-6, 2002. ing to a given mass value is limited, and from a mass measurement made to an accuracy of $<5 \mathrm{ppm}$ an elemental composition can be deduced when valence rules and additional chemical information is considered [2-4]. Traditionally, accurate mass measurements on low molecular weight organic molecules have been performed using high-resolution double-focusing magnetic-sector instruments [2, 4-9], although Fouriertransform ion-cyclotron-resonance (FTICR) instruments [10] and orthogonal-acceleration time-of-flight (OATOF) instruments [11-15] also are currently being used for this application. Magnetic-sector instruments have been manufactured with the capability of achieving resolutions in excess of 100,000 (10\% valley definition) 
for electron ionization applications [16], and FTICR instruments can achieve resolutions in excess of 200,000 (full-width at half-maximum-height [FWHM] definition) in the electrospray (ES) analysis of large biomolecules [10]. Such a resolution is sufficient to resolve the isotopic peaks of large multiply charged proteins and even isotope fine structure, that is, peaks corresponding to species of different elemental compositions [17, 18]. Although the application of FTICR mass spectrometry is becoming increasingly widespread, until very recently the technique has required a considerable degree of operational skill, and it is only now that the FTICR mass spectrometer is becoming an instrument of choice in biological mass spectrometry laboratories.

Although often considered together, high-resolution is not synonymous with accurate mass [19], and, in fact, the realization by Beynon in 1954 of the value of accurate measurements for the determination of elemental composition was first made with data produced by a single-focusing magnetic-sector instrument capable of only modest resolution (250, 10\% valley definition) [1]. It should be remembered, however, that if the accurate mass of a compound is to be reliably determined, it is necessary to work with sufficient resolution so that homogenous peaks are mass measured. Quadrupole instruments operated at unit mass resolution have produced accurate mass data on ES ionized pure compounds [20], and, currently, OA-TOF instruments are widely used in both chemistry and biochemistry laboratories for accurate mass measurements [11-15]. The popularity of OA-TOF instruments is a consequence of their high sensitivity, moderately high resolving power, and, perhaps most importantly, ease of operation [11].

The accurate mass of a protein is an important but often difficult to measure, property [21]. An accurate determination of protein mass gives information on posttranslational modifications (e.g., disulfide bridges or polymorphisms) [8, 21]. Recently, Rai and coworkers have demonstrated the accurate mass measurement (i.e., the abundance-weighted average-mass centroid, obtained after data processing) of human hemoglobin $(\mathrm{Hb})$ variants using a triple quadrupole instrument [22]. The authors used the normal $\alpha$-chain $\mathrm{Hb}$ peaks present in the $\mathrm{Hb}$ mass spectrum for internal calibration of the mass scale. Through optimization of the number of data points sampled per $m / z$ unit and the input parameters of the data analysis process, it was possible to detect heterozygous $\beta$-chain $\mathrm{Hb}$ variants, even when they were unresolved from the normal $\beta$-chain $\mathrm{Hb}$ and differed in mass by only $1 \mathrm{Da}$.

In the current study we have focused our attention on the mass spectrometric measurement of nuclear receptor (NR)-ligand complexes. NRs are ligand-activated transcription factors [23], and studies of the noncovalent interactions between NRs and their ligands using ES mass spectrometry have been reported [24-28]. We have previously investigated the binding of fatty acids to the retinoid $X$ receptor $\alpha(R X R \alpha, N R 2 B 1)$ ligand binding domain
(LBD) using nondenaturing ES mass spectrometry [28]. Fatty acid-receptor complexes were observed but were not analyzed with sufficient mass accuracy to allow the degree of fatty acid unsaturation to be determined directly. This was a significant drawback of that study because ligand binding (and activity) is related to the degree of fatty acid unsaturation [29].

Several NR subfamilies have been shown to be involved in lipid metabolism, for example, peroxisomeproliferator-activated receptors [30], liver $X$ receptors $[31,32]$, and farnesoid $X$ receptors $[33,34]$, and it has been shown that $\operatorname{RXR} \alpha$ can bind to and be activated by free fatty acids [29, 35-37]. NRs including orphan receptors, that is, receptors with as yet unidentified ligands [38], are regarded as important potential drug targets, and the identification and characterization of ligands for NRs is highly relevant to the pharmaceutical industry. One possible way to identify such ligands is by the use of nondenaturing ES mass spectrometry to measure the mass of receptor-ligand complexes [39].

Although several examples of the use of ES mass spectrometry to show ligand binding to NRs have been reported, there is always a doubt as to the specificity of the observed interactions. Thus, one of the goals of the current study was to show that the receptor-ligand binding observed by mass spectrometry was indeed specific. In addition, this study aimed at maximizing the degree of mass accuracy obtainable in the direct measurement of bound-ligand mass. Noncovalent complexes between the human RXR $\alpha$ LBD (relative molecular mass $\left.M_{\mathrm{r}} 31,370.92\right)$ and the unsaturated fatty acids, docosahexaenoic acid (DHA, C22:6), oleic acid (C18:1), and linolenic acid (C18:3), as well as synthetic agonists LG268 and XCT0315908, were used as a model system. The fatty acids are low-affinity ligands that have been shown to activate the RXR $\alpha$ in transfection studies [36] and bind to the RXR $\alpha$ LBD by nondenaturing ES mass spectrometry [28]. The synthetic agonist XCT0315908 specifically activates RXR in the context of the RXR Nurr1 (NR related 1, NR4A2) heterodimer [40], but to our knowledge, direct binding of this compound to the RXR LBD has not been shown.

\section{Experimental Procedures}

\section{Reagents and Solutions}

Oleic acid (cis-9-octadecenoic acid, C18:1), cis-4,7,10,13, 16,19-DHA (C22:6), and 17 $\beta$-estradiol $\left(E_{2}\right)$ were from Sigma-Aldrich Sweden AB (Stockholm, Sweden). LG268 was from Tularik, Inc. (South San Francisco, CA). Linolenic acid (cis-9,12,15-octadecatrienoic acid, C18:3) was from Larodan Fine Chemicals AB (Malmö, Sweden). XCT0315908 was from X-Ceptor Pharmaceuticals, Inc. (San Diego, CA). Ligand stock solutions (10 $\mathrm{mM}$ ) were prepared in $99.5 \%$ ethanol except for XCT0315908, which was prepared in 90\% ethanol, 10\% dimethylsulfoxide (DMSO). Milli-Q-purified deionized water was used for all buffers. 


\section{Protein Expression}

Human RXR $\alpha$ LBD, amino acids 203-462, was expressed as a $\mathrm{His}_{6}$-tag fusion protein in Escherichia coli and purified under nondenaturing conditions in the absence of ligand. Purified protein was dialyzed against $50 \mathrm{mM}$ of ammonium acetate, $\mathrm{pH} 8$, and aliquots were frozen at $-80{ }^{\circ} \mathrm{C}$ until analyzed. To asses the functionality of the expressed protein, the RXR LBD construct also was purified in the presence of 9-cis-retinoic acid and analyzed by analytical size-exclusion chromatography essentially ${ }^{\circ}$ as $^{\circ}$ described $^{\circ}$ by $^{\circ}$ Egea $^{\circ}$ et $^{\circ}$ al. $^{\circ}[41] .^{\circ}$ The ${ }^{\circ}$ agonist induced a significant reduction in the amount of apotetrameric RXR LBD and in the formation of the dimeric holo-protein. This is in accordance with previously published results for the behavior of RXR LBD in solution [41-43] and shows that the expressed protein is fully functional with respect to ligand binding and multimerization.

\section{Mass Spectrometry}

Data were acquired on a Micromass QTOF Ultima mass spectrometer, (Micromass Plc., Manchester, UK) equipped with a Z-spray source, operated in the positive-ion mode under the control of MassLynx v3.5 software (Micromass, Manchester, UK). The capillary voltage was $3.0 \mathrm{kV}$. The source block temperature was set to $120{ }^{\circ} \mathrm{C}$ to promote solvent evaporation. The desolvation gas flow was 210 $\mathrm{L} / \mathrm{h}$ at a temperature of $100{ }^{\circ} \mathrm{C}$. To maintain receptorligand noncovalent complexes, it was necessary to optimize the source offset voltage potentials; specifically the "rf lens" and "cone voltage" settings were optimized between 16.0 and $20.0 \mathrm{~V}$ and 31 and $35 \mathrm{~V}$, respectively. The pumping to the ES interface region was throttled, bringing the reading on the "backing" Pirani vacuum gauge up from ${ }^{\circ} 1.8^{\circ}$ to $^{\circ} 2.0^{\circ} \mathrm{mbar}^{\circ}[44] .^{\circ}\left(\right.$ In $^{\circ}$ subsequent ${ }^{\circ}$ work $^{\circ}$ using ${ }^{\circ}$ the QTOF Ultima instrument we have found that increasing the source pressure is nonobligatory to maintain NRligand complexes.) The collision cell was pressurized using argon, and the collision voltage was set to $5.0 \mathrm{~V}$ unless otherwise indicated. The instrument was operated in single reflectron mode at a resolution of $\sim 11,000$ (FWHM definition).

\section{Sample Analysis}

Protein stock solution ( $\sim 158 \mathrm{pmol} / \mu \mathrm{L}$ of $\mathrm{RXR} \alpha \mathrm{LBD}$ and $50 \mathrm{mM}$ of ammonium acetate, $\mathrm{pH}$ 8) was diluted 158 -fold in $10 \mathrm{mM}$ of ammonium acetate, $\mathrm{pH} 8$, to give a protein concentration of $1 \mathrm{pmol} / \mu \mathrm{L}$. The $10 \mathrm{mM}$ of ammonium acetate buffer was freshly prepared to minimize the degree of ammonium acetate adducts to the protein. The apo-RXR $\alpha$ LBD protein $(1 \mathrm{pmol} / \mu \mathrm{L}, 10 \mathrm{mM}$ ammonium acetate, $\mathrm{pH} 8$ ) was analyzed before all protein-ligand analyses and the dominant species was found to correspond to the $[\mathrm{M}+13 \mathrm{H}]^{13+}$ to $[\mathrm{M}+11 \mathrm{H}]^{11+}(13+$ to $11+$ ) charged states of the monomeric protein, forming $a^{\circ}$ peak $^{\circ}$ envelope ${ }^{\circ}$ in $^{\circ}$ the $2400-2900^{\circ} \mathrm{m} / \mathrm{z}$ range ${ }^{\circ}$ (Figure ${ }^{\circ} 1 \mathrm{a}$ ).
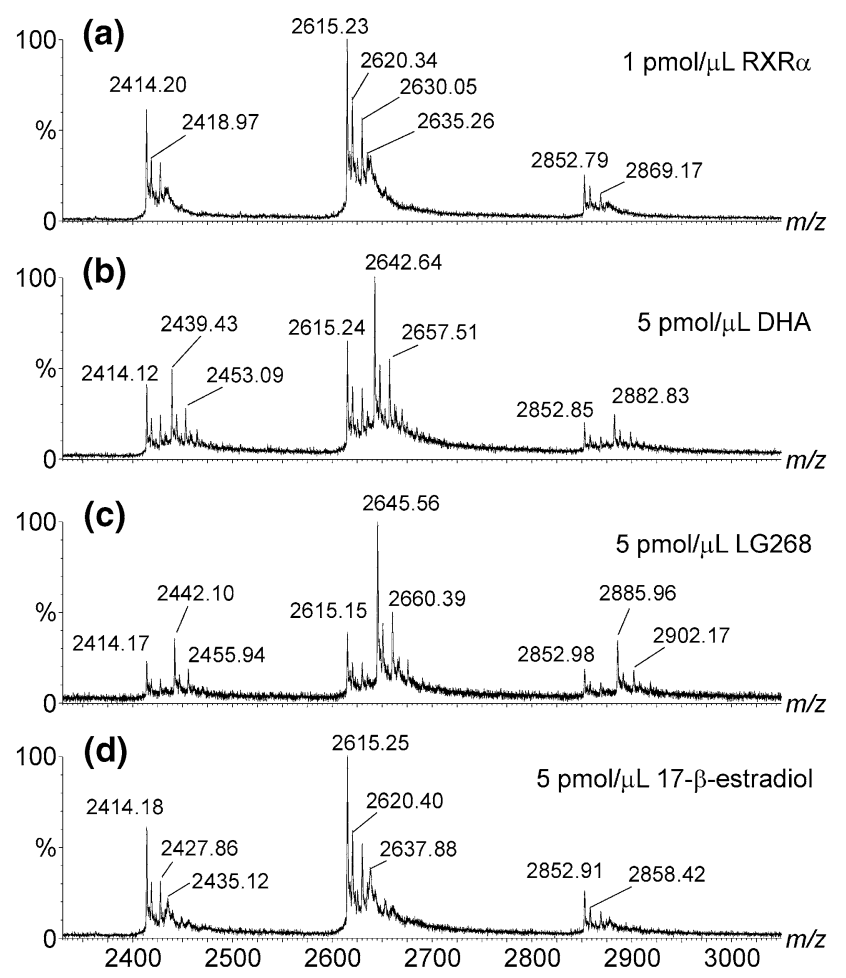

Figure 1. ES mass spectra (raw data) of agonists and a nonagonist after addition to $\operatorname{RXR} \alpha$. (a) $\operatorname{RXR} \alpha \operatorname{LBD}(1 \mathrm{pmol} / \mu \mathrm{L})$ alone; or in the presence of $5 \mathrm{pmol} / \mu \mathrm{L}$ of (b) DHA, (c) LG268, or (d) $\mathrm{E}_{2}$. The $[\mathrm{M}+13 \mathrm{H}]^{13+}$ to $[\mathrm{M}+11 \mathrm{H}]^{11+}$ charge state are shown in each spectrum.

For ligand binding experiments, test compound stock solution (10 mM in $99.5 \%$ ethanol or 9:1 ethanol/ DMSO) was added to give a fivefold excess of ligand to protein (i.e., $5 \mathrm{pmol} / \mu \mathrm{L}$ of test compound). For the analyses of fatty acid mixtures each fatty acid was added to give a concentration of $2.5 \mathrm{pmol} / \mu \mathrm{L}$ (total fatty acid concentration of $5 \mathrm{pmol} / \mu \mathrm{L}$ ). Samples were vortexed and left to equilibrate for at least $15 \mathrm{~min}$. at room temperature before starting sample infusion. The sample was delivered to the ES interface at a flow rate of $5 \mu \mathrm{L} / \mathrm{min}$ using a Harvard syringe pump. Data were acquired over the $\mathrm{m} / \mathrm{z}$ range $1000-4500$ until $\sim 1000$ counts were obtained for the least abundant ion of interest, that is, any of the $13+$ to $11+$ charge states of the apo- or holo-RXR $\alpha$ LBD species, to give satisfactory ion statistics. Mass measurements were performed after averaging 35 or 100 scans (5-s scan time).

\section{Internal Mass Calibration}

Data analysis was performed using the MassLynx v3.5 software package supplied by the instrument manufacturer ${ }^{\circ}$ and $^{\circ}{ }^{\circ}$ as $^{\circ}$ essentially ${ }^{\circ}$ as $^{\circ}$ previously ${ }^{\circ}$ described $^{\circ}[22]$. Briefly, each raw spectrum $(\mathrm{m} / \mathrm{z}$ range, 2350-2950, encompassing the $13+$ to $11+$ charge states) was first background subtracted using a 25th order polynomial such that $5 \%$ fell below the new base line. The subtracted spectrum was smoothed $(2 \times 20$ channels, 
Savitzky Golay smooth). The mass centroid values of the subtracted and smoothed peaks were obtained using $20 \%$ of the peak top and a minimum peak width setting of 45 channels (determined empirically to be suitable given the peak width of the $\operatorname{RXR} \alpha$ LBD and its ligand-complex peaks). Internal calibration was performed using a single-order polynomial and apo-RXR $\alpha$ LBD peaks (i.e., the $13+$ to $11+$ charge states). Note that the number of data points per $m / z$ was the standard 16 data points for the acquired data, which is the maximum when the standard MassLynx software is used.

\section{Mass Measurement}

Each background subtracted spectrum $(\mathrm{m} / \mathrm{z}$ range, 23502950) was deconvoluted onto a true mass scale using the maximum entropy-based Maxent 1 function of the MassLynx ${ }^{\circ}$ software ${ }^{\circ}$ package $^{\circ}\left[45,{ }^{\circ} 46\right] .^{\circ}$ The $^{\circ}$ processing parameters were "output mass range" of 31,000-32,500 Da at a "resolution" of $0.1 \mathrm{Da} /$ channel; the "simulated isotope pattern" model was used with the "spectrum blur width" parameter set to $0.2 \mathrm{Da}$; the "minimum intensity ratios" between successive peaks were $20 \%$ (left and right). Each deconvoluted spectrum was then smoothed ( $2 \times 3$ channels, Savitzky-Golay smooth) and the mass centroid values were obtained using $90 \%$ of the peak top and a minimum peak width at half height of 45 channels. The mass of the bound ligand was obtained by subtracting the measured mass value for the apo-protein (apo-RXR) from the measured mass of the receptor-ligand complex (holo-RXR).

\section{Results and Discussion}

\section{Specificity of Ligand Binding}

The $\operatorname{RXR} \alpha$ has been shown to be activated by the polyunsaturated fatty acid DHA $\left(M_{\mathrm{r}} 328.49\right.$, all $M_{\mathrm{r}}$ values $^{\circ}$ were $^{\circ}$ calculated $^{\circ}$ from $^{\circ}$ data $^{\circ}$ from $\left.{ }^{\circ} \operatorname{Ref}^{\circ}[47]\right)^{\circ}[36]$. The receptor-ligand complex formed between this lowaffinity agonist and the RXR $\alpha$ LBD is clearly observed by peaks at $m / z 2439.43,2642.64$, and 2882.83, corresponding to the $13+$ to $11+$ charge states of the complex $^{\circ}\left(\right.$ Figure $\left.^{\circ} 1 \mathrm{~b}\right) .^{\circ}$ The $^{\circ}$ high-affinity ${ }^{\circ}$ agonist $^{\circ} \mathrm{LG} 68^{\circ}\left(M_{\mathrm{r}}\right.$ 363.49) forms a more stable complex with the $\operatorname{RXR} \alpha$ LBD than does DHA, as is indicated by the more intense peaks for the holo-receptor $(\mathrm{m} / \mathrm{z} 2442.10,2645.56$ and

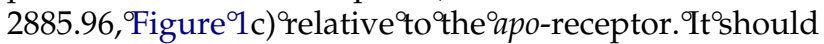
be noted that the intensity of holo-receptor peaks is a reflection of both the gas-phase and solution-phase receptor-ligand binding affinity.

A solution containing $E_{2}\left(M_{r} 272.39\right)$ and the $R X R \alpha$ LBD was analyzed in a control experiment. The resultant $^{\circ}$ mass $^{\circ}$ spectrum $^{\circ}\left(\text { Figure }^{\circ} 1 \mathrm{~d}\right)^{\circ}$ was $^{\circ}$ similar $^{\circ}$ to ${ }^{\circ}$ that ${ }^{\circ}$ of ${ }^{\circ}$ the apo-RXR sample (Figure $1 \mathrm{a}$ ) but $^{\circ} \mathrm{does}^{\circ}$ show $^{\circ}{ }^{\circ}$ minor ${ }^{\circ}$ degree of receptor-lipid complex formation. A minor peak is observed at $m / z 2637.88$, corresponding to the $12+$ charge state ${ }^{\circ}$ f $^{9} e^{\circ}$ complex $^{\circ}\left(\right.$ Figure $\left.^{\circ} 1 \mathrm{~d}\right)$. This indicates ${ }^{\circ}{ }^{\circ}$ degree $^{\circ}$ of nonspecific protein-lipid binding, but the intensity of protein- $E_{2}$ peaks are much lower than those that correspond to specific receptor-ligand binding between $\operatorname{RXR} \alpha$ $\operatorname{LBD}^{\circ}$ and ${ }^{\circ}$ the ${ }^{\circ}$ two $^{\circ}$ agonists $^{\circ}\left(\right.$ Figure $^{\circ} 1 \mathrm{~b},{ }^{\circ} \mathrm{C}$ ).

\section{High-Accuracy Mass Measurement of Receptor Bound Ligands}

By averaging 35 mass scans (5 s/scan), spectra were obtained with sufficient signal-to-noise ratio to allow the accurate mass determination of the holo-RXR $\alpha$ LBD complex ${ }^{\circ}$ with ${ }^{\circ} \mathrm{DHA}^{\circ}\left(\text { Figure }^{\circ} \mathrm{a}\right)^{\circ}{ }^{\circ}$ and $^{\circ}$ with ${ }^{\circ}$ the $e^{\circ}$ wo ${ }^{\circ}$ other unsaturated fatty acids, that is, oleic acid and linolenic acid (C18:1, $M_{\mathrm{r}}$ 282.47; and C18:3, $M_{\mathrm{r}}$ 278.44; data not shown). The two C-18 unsaturated fatty acids have been shown to activate the $\mathrm{RXR} \alpha$ in transfection experiments but $^{\circ}$ with $^{\circ}$ lower $^{\circ}$ efficacy $^{\circ}$ than $^{\circ} \mathrm{DHA}^{\circ}\left[36,{ }^{\circ} 37\right] .{ }^{\circ}$ Shown ${ }^{\circ}$ in Figure ${ }^{\circ} 2 a^{\circ}$ is ${ }^{\circ} a^{\circ}$ representative ${ }^{\circ}$ background $^{\circ}$ subtracted and internally calibrated spectrum (35 scans of raw data, not smoothed) of a 1-pmol/ $\mu \mathrm{L} R \mathrm{RXR} \alpha$ solution with an excess of DHA added $(5 \mathrm{pmol} / \mu \mathrm{L})$. The RXR $\alpha-$ DHA complex is observed by peaks at $m / z 2439.48$, 2642.63 , and 2882.80 for the three charge states, $13+$ to $11+$. Gluconoylated apo- and holo-protein is indicated by ${ }^{\circ}$ peaks 9 labeled ${ }^{\circ} y^{\circ}$ filled $^{\circ}$ circles. $^{\circ}$ Shown ${ }^{\circ}{ }^{\circ}{ }^{\circ}$ Figure $2 \mathrm{~b}$ is the corresponding deconvoluted spectrum. For accurate mass measurements, the deconvoluted spectrum is subsequently smoothed and centroided to obtain the apoand holo-RXR accurate mass values. The masses of the bound ligands were determined to be $M_{\mathrm{r}} 328.69$ (DHA, standard deviation [SD], 0.07; $n=12), \mathrm{M}_{\mathrm{r}} 282.62$ (C18:1, SD, $0.08 ; n=10)$ and $M_{\mathrm{r}} 278.44(\mathrm{C} 18: 3, \mathrm{SD}, 0.19 ; n=10$; Table $\left.^{\circ} 1\right) .^{\circ}$ These $^{\circ}$ values $^{\circ}$ correspond $^{\circ}$ to $^{\circ}$ average ${ }^{\circ}$ massmeasurement errors of $0.20,0.16$, and 0.002 Da, corresponding to $6.3,5.1$, and $0.06 \mathrm{ppm}$ in the respective receptor-ligand ${ }^{\circ} \operatorname{complexes}^{\circ}\left(\right.$ Table $\left.^{\circ} 1\right) .{ }^{\circ}$ Shown ${ }^{\circ}$ in ${ }^{\circ}$ Table $^{\circ} 1$ also are the SDs of the measured mass values for holoand apo-RXR species (columns F and G). It is noteworthy that the SDs for the holo-complexes are always higher than those for the apo-protein.

The fact that the RXR $\alpha$ can be activated by a number of unsaturated ${ }^{\circ}$ fatty $^{\circ}$ acids $^{\circ}\left[36,{ }^{\circ} 37\right]^{\circ}$ highlights $^{\circ}$ the ${ }^{\circ}$ importance of performing experiments in which the receptor can potentially interact with more than one ligand. Initially, the simplest experiment was performed in which an equimolar mixture of DHA and oleic acid was added to the $\operatorname{RXR} \alpha$ LBD sample solution to give a final concentration of $2.5 \mathrm{pmol} / \mu \mathrm{L}$ of each fatty acid. Both fatty acids formed a complex with $\operatorname{RXR} \alpha$ LBD and the masses of the ligands were measured to be $M_{\mathrm{r}} 328.66$ and $M_{\mathrm{r}} 282.49$ (SD, 0.15 and 0.12 , respectively; $n=13$ ). These measured values corresponded to mass measurement errors of 0.17 $\mathrm{Da}^{\circ}(\mathrm{DHA})^{\circ}$ and ${ }^{\circ} 0.02^{\circ} \mathrm{Da}^{\circ}$ (oleic ${ }^{\circ}$ acid; $^{\circ}$ Figure $^{\circ} 2 \mathrm{c}^{\circ}{ }^{\circ} \mathrm{d} ;{ }^{\circ} \mathrm{Table}^{\circ} 1$ ).

\section{Differentiation Between $R X R \alpha$ LBD Binding} to a Single Ligand or to Multiple Ligands

For the analyses of complex mixtures containing more than one potential ligand, a problem to be confronted is 


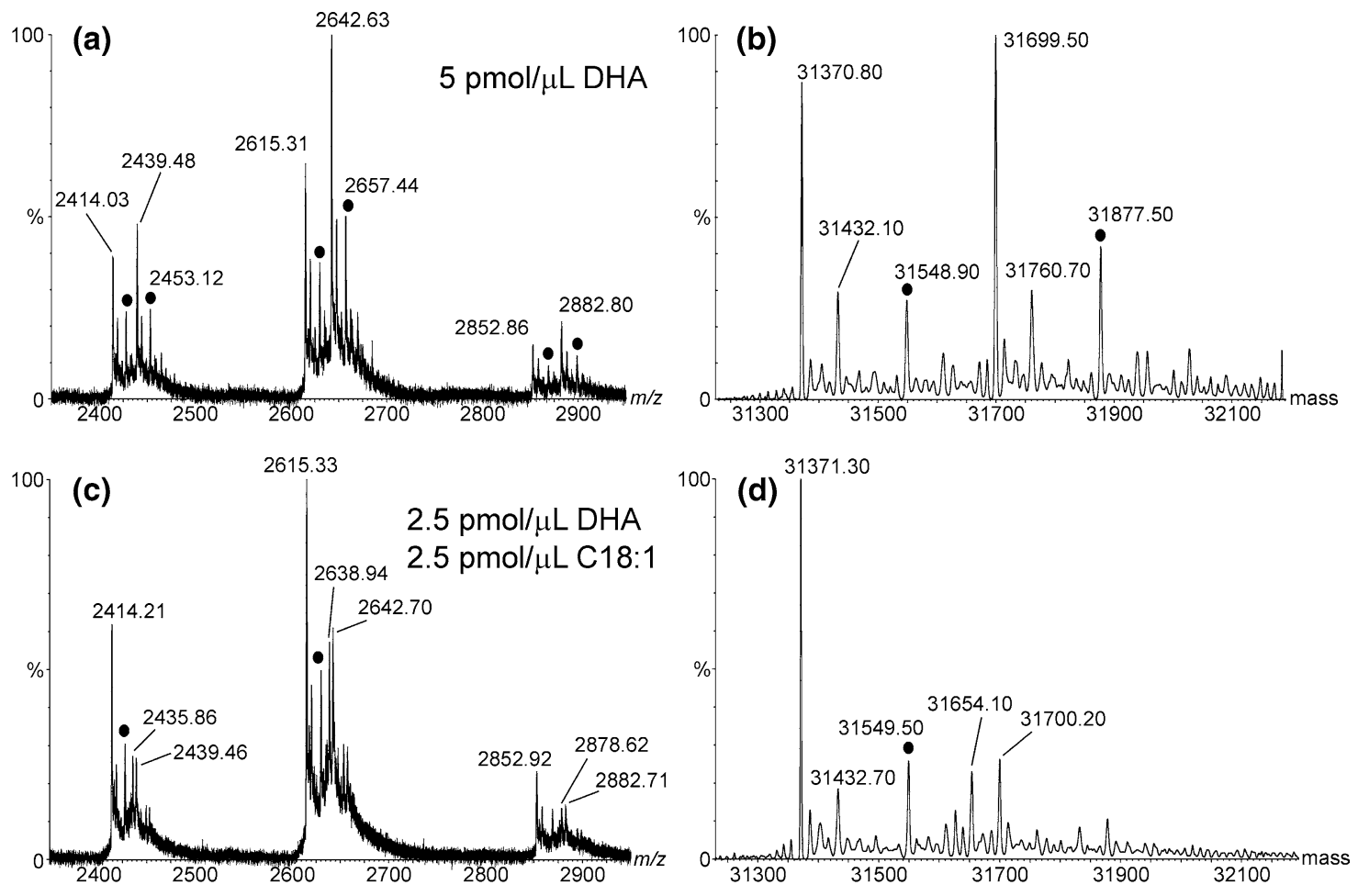

Figure 2. The unsaturated fatty acids DHA and oleic acid bind to the RXR $\alpha$ LBD. (a) Baseline subtracted raw data spectra (35 scans) of $\operatorname{RXR} \alpha \operatorname{LBD}(1 \mathrm{pmol} / \mu \mathrm{L})$ with the addition of a fivefold excess of DHA; or (c) a 2.5-fold excess each of DHA and oleic acid. The $m / z$ ranges covering the $13+$ to $11+$ charge states are shown. (b and $\mathbf{d}$, respectively) The corresponding deconvoluted spectra are shown after internal calibration. Gluconoylated RXR $\alpha$ LBD is indicated by a filled circle in panels a-d.

the simultaneous binding of multiple ligands that are sufficiently close in mass so that resolution of holoprotein peaks on the $\mathrm{m} / \mathrm{z}$ scale will be impossible. To investigate the possibility of analyzing such unresolved ligand-protein complexes and to observe their effect on the mass measurement of the holo-protein, we analyzed linolenic $\left(\mathrm{m}_{\mathrm{r}} 278.44\right)$ and oleic acid $\left(M_{\mathrm{r}} 282.47\right)$, initially by adding each acid separately to the protein and then as $^{\circ}{ }^{\circ}{ }^{\circ}$ equimolar ${ }^{\circ}$ mixture $^{\circ}$ (Figure ${ }^{\circ} 3 a-\varepsilon,{ }^{\circ} 700-1000^{\circ}$ scans / spectrum, $5 \mathrm{~s} / \mathrm{scan})$. When the apo-receptor peaks from the three experiments were superimposed they were found ${ }^{\circ}$ to $^{\circ}$ almost ${ }^{\circ}$ exactly $^{\circ}$ coincide $^{\circ}$ (Figure ${ }^{\circ}$ d), indicating that any drift of the instrument mass scale over the

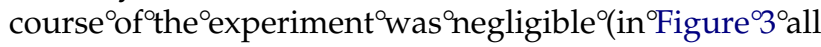

Table 1. Determination of the mass of polyunsaturated fatty acid ligands when part of RXR $\alpha$ LBD-fatty acid noncovalent complexes (35 or 100 scans were averaged for each mass measurement as indicated).

\begin{tabular}{|c|c|c|c|c|c|c|}
\hline \multirow{3}{*}{$\frac{A}{\text { Compound }}$} & B & C & & $\mathrm{E}$ & $\mathrm{F}$ & G \\
\hline & \multirow{2}{*}{$\begin{array}{c}\text { Average, } \\
\text { observed } M_{\mathrm{r}}\end{array}$} & \multirow{2}{*}{$\begin{array}{c}\text { SD, observed } \\
M_{\mathrm{r}}\end{array}$} & \multirow{2}{*}{$\frac{\mathrm{D}}{\text { Theoretical } M_{\mathrm{r}}}$} & \multirow{2}{*}{$\begin{array}{c}\text { Average } \\
\text { error }\end{array}$} & \multirow{2}{*}{$\begin{array}{c}\mathrm{SD} \\
\text { holo-RXR }\end{array}$} & \multirow{2}{*}{$\begin{array}{c}\mathrm{SD} \\
\text { apo-RXF }\end{array}$} \\
\hline & & & & & & \\
\hline \multicolumn{7}{|l|}{36 Scans } \\
\hline$D H A(n=12)$ & 328.693 & 0.074 & 328.495 & 0.198 & 0.119 & 0.070 \\
\hline Oleic acid $(n=10)$ & 282.623 & 0.083 & 282.467 & 0.156 & 0.137 & 0.085 \\
\hline Linolenic acid $(n=9)$ & 278.437 & 0.186 & 278.435 & 0.002 & 0.232 & 0.068 \\
\hline \multicolumn{7}{|l|}{$\begin{array}{l}\text { DHA + oleic acid } \\
\quad(n=13)\end{array}$} \\
\hline DHA & 328.662 & 0.145 & 328.495 & 0.167 & 0.164 & 0.069 \\
\hline oleic acid & 282.489 & 0.122 & 282.467 & 0.022 & 0.166 & 0.069 \\
\hline \multicolumn{7}{|l|}{100 Scans } \\
\hline $\begin{array}{l}\text { Linolenic acid } \\
\quad(n=10)\end{array}$ & 278.410 & 0.147 & 278.435 & 0.025 & 0.203 & 0.07 \\
\hline Oleic acid $(n=9)$ & 282.323 & 0.098 & 282.467 & 0.143 & 0.133 & 0.091 \\
\hline $\begin{array}{l}\text { Linolenic }+ \text { oleic acid } \\
\quad(n=10)\end{array}$ & 280.567 & 0.244 & $280.451=(278.435+282.467) / 2$ & 0.116 & 0.131 & 0.133 \\
\hline
\end{tabular}

The table shows, by column, the average of the measured $\mathrm{M}_{\mathrm{r}}$ values (B); the SD of those measurements (C); theoretical $M_{\mathrm{r}}$ values (D); the average mass error for each compound (E); and the SDs of the holo-RXR and apo-RXR ( $F$ and $G$, respectively) measurements. 


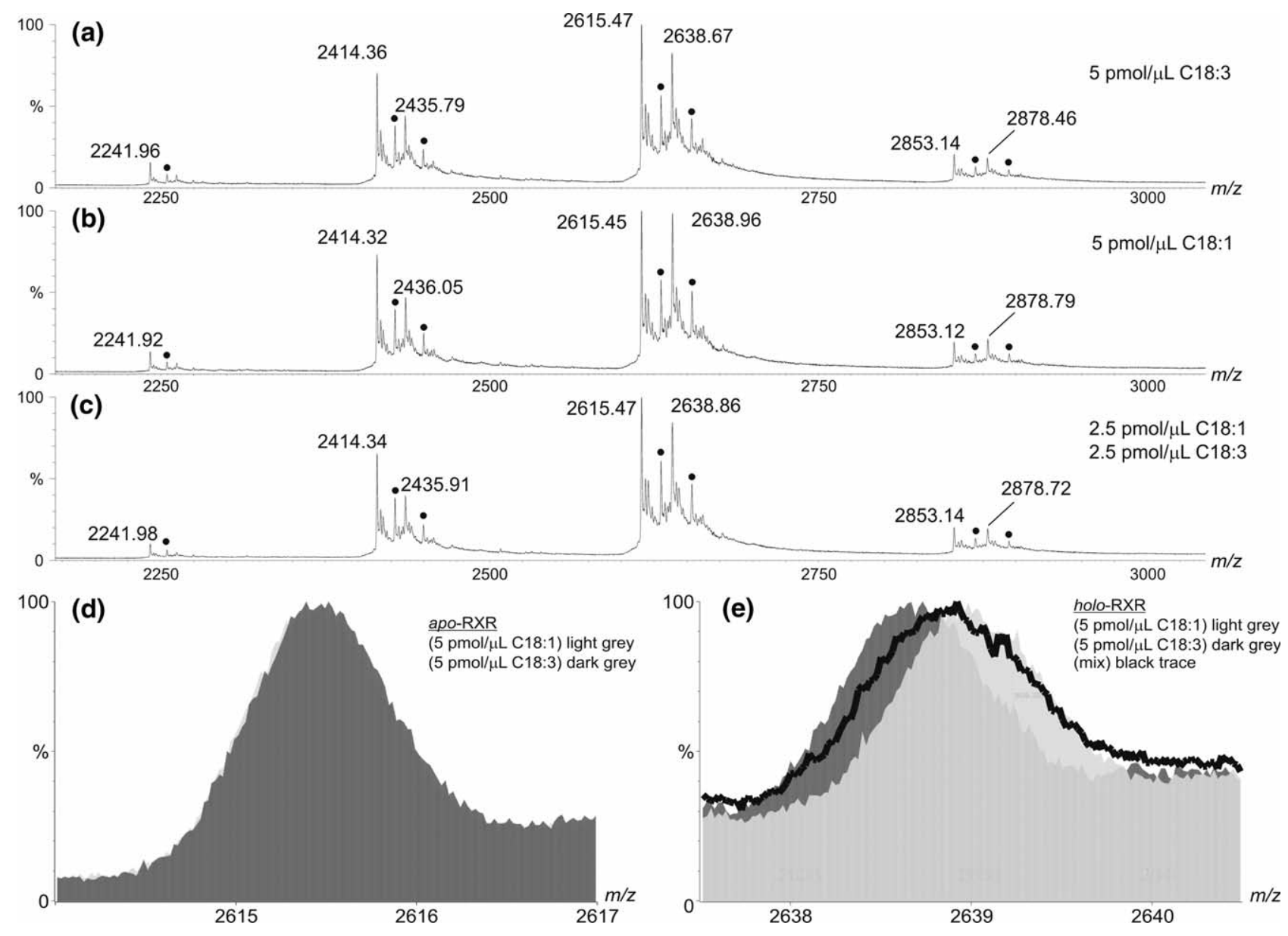

Figure 3. Analysis of unresolved receptor-ligand complexes. Mass spectra (raw data, 700-1000 scans, $5 \mathrm{~s} / \mathrm{scan}$ ) of RXR $\alpha \mathrm{LBD}, 1 \mathrm{pmol} / \mu \mathrm{L}$ in the presence of (a) linolenic acid (C18:3); $5 \mathrm{pmol} / \mu \mathrm{L}$ (b)oleic acid (C18:1), $5 \mathrm{pmol} / \mu \mathrm{L}$; and (c) a mixture of both oleic acid, $2.5 \mathrm{pmol} / \mu \mathrm{L}$, and linolenic acid, 2.5 $\mathrm{pmol} / \mu \mathrm{L}$ are shown without internal calibration. Superimposed raw data spectra from panels a-c, showing the (d) apo- and the (e) holo-receptor peaks for the 12+ charge state. (d and e) Oleic acid peaks are in light-grey fill, linolenic acid peaks are in dark-grey fill, and the outline of the holo-RXR $\alpha$ peak corresponding to mixed binding of oleic and linolenic acid is indicated by a black line (in panel e).

spectra are shown without internal calibration). In contrast, the holo-receptor peaks from the three experiments did not coincide. It is evident that for the holoreceptor complex, introduction of an additional two double bonds to the C18:1 template causes a distinct translocation ${ }^{\circ}$ of $^{\circ}$ the ${ }^{\circ}\left[\mathrm{M}^{\circ}+{ }^{\circ} 12 \mathrm{H}\right]^{12+^{\circ}}$ peak $^{\circ}\left(\right.$ Figure $^{\circ} 3 \mathrm{e}$ ). When an equimolar mixture of the two ligands was analyzed, the working resolution of the instrument was insufficient to resolve the two holo-receptor complexes (Figure $\left.{ }^{\circ} 3 \mathrm{e}\right) .{ }^{\circ}$ However, ${ }^{\circ}$ the ${ }^{\circ}$ holo-receptor ${ }^{\circ}$ complex $^{\circ}$ was found to give a peak that was centered amid the two individual holo-receptor peaks. This is illustrated further in Figure 4 , ${ }^{\circ}$ where 9 individual ${ }^{\circ}$ xperimental ${ }^{\circ}$ easurements of ligand mass are plotted (100 scans, $5 \mathrm{~s} / \mathrm{scan}$ ) after incorporation of $5 \mathrm{pmol} / \mu \mathrm{L}$ of either oleic acid (C18:1, labeled by filled circles), linolenic acid (C18:3, labeled by filled squares), or an equimolar mix of the two ("mix," labeled by filled triangles). In these experiments, the average of the measured ligand $M_{\mathrm{r}}$ values were 282.32 $(\mathrm{SD}, 0.10 ; n=9)$ and 278.41 (SD, $0.15 ; n=10)$, respectively, for oleic acid and linolenic acid when analyzed separately. For the mixture analyses, the average measured $M_{\mathrm{r}}$ of the bound ligands was $280.57 \mathrm{Da}(\mathrm{SD}, 0.25 ; n=10)$. This mass value is approximately the mean mass of the two ligands, indicating that both ligands are bound with an approximately equal overall affinity (i.e., combined solution and gas-phase affinity) to the receptor.

As a possible means for identifying the binding of multiple ligands close in mass, the peak width of holo-RXR $\alpha$ complexes were compared. The FWHM of the $\mathrm{C} 18: 1$ and $\mathrm{C} 18: 3$ holo-receptor peaks were 1.28 and $1.37 \mathrm{Da}$, respectively. For the mixture of ligands, the peak width increased to $1.59 \mathrm{Da}$.

\section{Binding of XCT0315908 to RXR $\alpha$ LBD}

The synthetic ligand XCT0315908 $\left(M_{\mathrm{r}} 345.40\right)$ has been identified ${ }^{\circ} \mathrm{as}^{\circ}{ }^{\circ}{ }^{\circ} \mathrm{RXR} \alpha^{\circ}$ agonist ${ }^{\circ}[40] .{ }^{\circ}$ However, ${ }^{\circ}$ direct $^{\circ}$ in vitro binding to the RXR $\alpha$ LBD has not been shown previously. Therefore, this compound was analyzed 


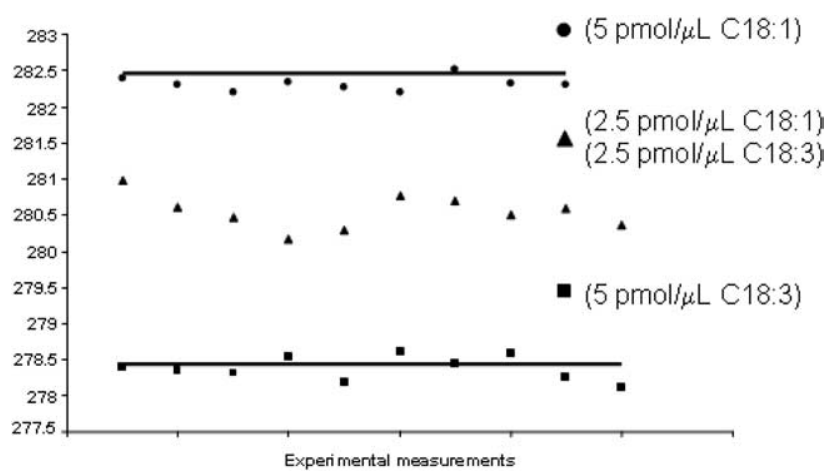

Figure 4. Individual experimental mass measurements (100 scans) of oleic acid (filled circles), linolenic acid (filled squares), and an equimolar mixture of the two fatty acids (filled triangles). For the fatty acids the theoretical $M_{\mathrm{r}}$ values are indicated by solid lines. ${ }^{\circ}$ Analysis ${ }^{\circ}$ performed ${ }^{\circ} a^{\circ}{ }^{\circ}{ }^{\circ}$ Figure $^{\circ} 3$.

using the current methodology. At a five-times excess of ligand to protein, the formation of $\operatorname{RXR} \alpha$ XCT0315908 complex was observed giving peaks $\mathrm{m} / \mathrm{z}$ $2440.79,2644.25,2884.52$, and 3172.72 for the $13+$ to $10+$ charge $^{\circ}$ states $^{\circ}$ (Figure 5 a). The $^{\circ}$ shift $^{\circ}$ of the ${ }^{\circ}$ peak-envelope maximum to higher $m / z$ (i.e., $11+$ rather than $12+$ ) may be an effect of the presence of DMSO added as part of the ligand stock solution. This effect has been observed previously $^{\circ}$ [27]. ${ }^{\circ}$ The $^{\circ}$ average $^{\circ}$ measured $^{\circ}$ mass $^{\circ}$ of ${ }^{\circ}$ the ligand was $345.37 \mathrm{Da}(\mathrm{SD}, 0.09 ; n=9$ ), which corresponds to a mass measurement error of $0.024 \mathrm{Da}$.

\section{Sample Consumption and Ligand Concentration}

Because of the high sensitivity of quadrupole TOF-type instruments, native protein samples (i.e., from aqueous solutions of near-neutral $\mathrm{pH}$ ) can be readily analyzed at concentrations of $1 \mathrm{pmol} / \mu \mathrm{L}$. To obtain high-quality data necessary to make accurate mass measurement on the receptor-ligand complexes, spectra were accumulated for at least $3 \mathrm{~min}$, but the total consumption of sample was always less than 15 pmol. In the ligand binding experiments the ligand concentration used was $5 \mathrm{pmol} / \mu \mathrm{L}$, which corresponds to the median effective concentration $\left(\mathrm{EC}_{50}\right)$ value for unsaturated fatty acids activating ${ }^{\circ} \mathrm{RXR} \alpha\left[36,{ }^{\circ} 37\right]$.

\section{Discussion}

The concept of using the natural affinity of a receptor protein for its cognate ligand to identify novel ligands from compound mixtures has, for many years, been at the basis of pharmaceutical screening and development programs. The analytical methods used have relied on the capacity of a "new" ligand to displace a predefined high-affinity ligand or on the recruitment of coactivator peptides by the ${ }^{9}$ receptor ${ }^{\circ}$ Iigand binding 948$]$. For true orphan receptors, for which there is an absence of known ligands and also interacting proteins partners, a direct method for detecting and identifying receptorligand complexes would be extremely valuable. In recent years, nondenaturing ES mass spectrometry has evolved to the point where noncovalent interactions are analyzed ${ }^{\circ}$ routinely $^{\circ}[49],{ }^{\circ}$ and $^{\circ}$ in $^{\circ}$ the $^{\circ}$ current $^{\circ}$ study ${ }^{\circ}$ we have used this methodology to investigate receptorligand complexes. We also have explored the possibility of determining the molecular weight of receptor-ligand complexes with a high degree of mass accuracy, because such measurements can then lead to a direct measurement of the mass of the bound ligand. Additionally, we have considered the question of binding specificity, in particular, the extent to which binding specificity can be retained in the ES mass spectrometry process.

$\operatorname{RXR} \alpha$ high- and low-affinity agonist ligands and in control experiments, a lipid with no known affinity for $\operatorname{RXR} \alpha$ were analyzed for binding to the receptor LBD. The agonists were shown by ES mass spectrometry to bind ${ }^{\circ}$ to ${ }^{\circ}$ the ${ }^{\circ} \operatorname{RXR}^{\circ} \operatorname{LBD}^{\circ}\left(\right.$ Figures $^{\circ} 1 b,{ }^{\circ} \mathrm{C} ;{ }^{\circ} 2 ;{ }^{\circ} 3 \mathrm{a},{ }^{\circ} \mathrm{b} ;{ }^{\circ}$ and $\left.{ }^{\circ} 5 \mathrm{a}\right)$. However, it should be emphasized that agonist efficacy is based both on the affinity of the ligand for the receptor and also on its ability to form productive protein contacts to stabilize the receptor-coactivator

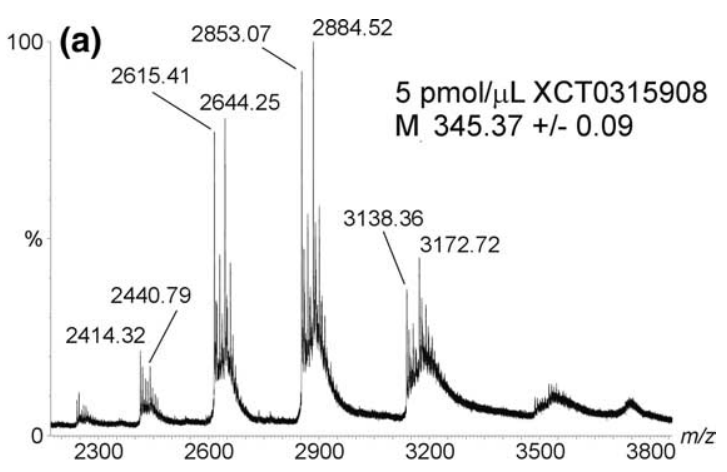

(b)

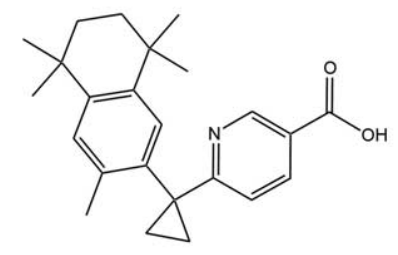

LG268, Mr 363.49<smiles>C=CCc1c(C)nc(-c2ccccc2)nc1Nc1ccc(C(=O)O)cc1</smiles>

ХСT0315908, Mr 345.40

Figure 5. The novel agonist XCT0315908 binds to the $\mathrm{RXR} \alpha \mathrm{LBD}$. (a) A raw mass spectrum of the $\mathrm{m} / \mathrm{z}$ range encompassing the major monomeric $\operatorname{RXR} \alpha$ charge state envelope $(13+$ to $10+)$ for a solution of $5 \mathrm{pmol} / \mu \mathrm{L}$ of XCT0315908 and $1 \mathrm{pmol} / \mu \mathrm{L}$ of RXR $\alpha$. (b) and (c) The structures of the high-affinity RXR $\alpha$ agonist LG268 and XCT0315908, respectively. 
protein complex. This may explain the discrepancy between the difference in the $\mathrm{EC}_{50}$ values of the agonists LG268 (nanomolar $\mathrm{EC}_{50}$ ) and DHA (micromolar $\mathrm{EC}_{50}$ ) and the more modest difference in the peak intensities for the holo-receptor complexes as observed by ES mass spectrometry ${ }^{\circ}$ (Figure $\left.{ }^{\circ} 1 \mathrm{~b},{ }^{\circ} \mathrm{C}\right) .^{\circ} \mathrm{A}^{\circ}$ minor $^{\circ}$ degree $^{\circ}$ of nonspecific binding was found to occur in the ES experiments, as is evident from the observation of a low-intensity peak corresponding to the $\mathrm{RXR} \alpha-17 \beta$-estradiol complex (Figure ${ }^{\circ} 1 \mathrm{~d}$ )..$^{\circ}$ This $^{\circ}$ was $^{\circ}$ not $^{\circ}$ an $^{\circ}$ unsurprising ${ }^{\circ}$ result, ${ }^{\circ}$ because during the repeated droplet fission events of the ES process, solvent is removed and surface-active components such as $\mathrm{E}_{2}$ become disproportionally enriched in the ultimate ion-forming droplet. High $\mathrm{E}_{2}$ concentrations in these droplets may then be the cause of the nonspecific binding being observed. However, clearly, the degree of nonspecific binding is much less than the binding of any $\mathrm{RXR} \alpha$ agonist compound to $\mathrm{RXR} \alpha$ (cf. Figure ${ }^{\circ} 1 d^{\circ}$ with $^{\circ} 1 b^{\circ}$ and $\left.{ }^{\circ} 1 \mathrm{c}\right) .^{\circ}$ It $^{\circ}$ also ${ }^{\circ}$ should ${ }^{\circ}$ be ${ }^{\circ}$ noted ${ }^{\circ}$ that nonspecific binding could be identified by performing a simple ligand exchange experiment, in which a highaffinity ligand is added to the solution containing the supposed nonspecifically bound ligand. If the binding is nonspecific, addition of a high-affinity ligand will simply elevate the mass of the complex by an amount equivalent to that of the added high-affinity ligand. If, alternatively, binding of the first ligand to the protein were specific and the first ligand is displaced by the second high-affinity ligand, the mass of the complex will be shifted by an amount equivalent to the differ-

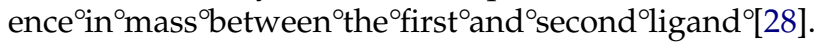

The main objective of the current study was to investigate whether the mass of receptor-ligand complexes could be measured with high mass accuracy. As with small molecules, the mass of denatured proteins can be measured with high accuracy. For example, Rai et al. have eloquently described a method for the accurate $^{\circ}$ mass $^{\circ}$ measurement ${ }^{\circ}$ of $^{\circ} \mathrm{Hb}^{\circ}$ variants $^{\circ}[22] .^{\circ}$ For such measurements high resolution was not required, and rather than measuring a monoisotopic mass, Rai et al. determined an accurate abundance-weighted mass (average mass, $M_{\mathrm{r}}$ ) for the $\mathrm{Hb}$ variants. In the current study we have applied a similar methodology to that of Rai et al. but used nondenaturing ES to determine the accurate mass of receptor-ligand complexes.

In experiments to determine an accurate $M_{\mathrm{r}}$ value of a receptor-ligand complex, the determination of the abundance-weighted peak centroid of the unresolved isotopic envelope is the critical measurement. This measurement will be influenced by peak shape. This is not a problem if the peak is Gaussian and drops to baseline, as is the case with a homogeneous peak from $a^{\circ}$ pure $^{\circ}$ denatured ${ }^{\circ}$ protein $^{\circ}[19]^{\circ}{ }^{\circ}$ However, ${ }^{\circ}$ when ${ }^{\circ}$ analyzing proteins under nondenaturing conditions these criteria are less well adhered to. In the current study the accurate mass of the holo-receptor protein was determined using the apo-receptor protein as an internal calibrant. In this case any differences in peak shape between the two sets will have a significant effect on mass measurement accuracy. To minimize this potential problem, it was necessary to optimize carefully the data-processing steps used in the mass determination process. Although any drastic differences in peak shape in the analyzed data were not immediately obvious, such factors may account for discrepancies between observed and theoretical mass values, as well as affecting the SD of these measurements. Most notably, there was an increased SD in the mass measurement of the holo-receptor from the mixture of oleic and linolenic acids $(0.24 \mathrm{Da})$, as compared with that for the holoreceptor when measured for the acids individually $\left(0.098^{\circ}\right.$ and $^{\circ} 0.15^{\circ} \mathrm{Da}^{\circ}{ }^{\circ}$ Figure $^{\circ} 3^{\circ}$ and $^{\circ}$ Table $\left.^{\circ} 1\right) .^{\circ}$ This $^{\circ}$ is explained by the holo-receptor peak shape for a mixture of unresolved competing ligands being less well defined than for a homogeneous peak. Ion addition, the $\mathrm{SD}$ for the holo-RXR $\alpha$ mass measurements were always higher than for the corresponding measurements of the apo-protein ${ }^{\circ}\left(\right.$ Table $^{\circ} 1,{ }^{\circ}$ columns $^{\circ} \mathrm{F}^{\circ}$ and $\left.^{\circ} \mathrm{G}\right){ }^{\circ}$ This $^{\circ}$ can $^{\circ}$ be rationalized in part by a greater influence of baseline variations on the holo- compared with apo-receptor peak shape $^{\circ}$ (see, ${ }^{\circ}$ e.g. ${ }^{\circ}$ Figure $\left.^{\circ} 2 \mathrm{a}\right),{ }^{\circ}$ that ${ }^{\circ}$ is, ${ }^{\circ}$ the ${ }^{\circ}$ holo-receptor peaks will tend to be less well defined. Despite using the apo-protein for internal calibration, its measured mass requires correction to obtain the full accuracy and precision. This is partly due to the mass being critically dependent on the peak width, which tends to change slightly over a series of analyses made over several hours $^{\circ}[22] .{ }^{\circ}$ Although ${ }^{\circ}$ reprocessing $^{\circ} a^{\circ}$ given $^{\circ}$ data $^{\circ}$ set $^{\circ}$ by MaxEnt could be undertaken to make the apo-protein mass equal its sequence mass by adjusting the peak width parameter, this is not necessary in the current study because all that is required is a simple measurement of the mass difference between the holo- and apo-protein to give the ligand mass.

Because the amino acid sequence of the recombinant $\mathrm{RXR} \alpha$ LBD protein is known, the nonliganded protein peaks in the mass spectrum were used for internal calibration. Each mass spectrum was independently calibrated, thereby reducing the influence of external factors such as temperature changes on the accuracy of the mass measurement. The mass measurement errors of $0.2,0.16$, and $0.002 \mathrm{Da}$ for DHA, oleic acid, and linolenic ${ }^{\circ}$ acid $^{\circ}{ }^{\circ}$ respectively ${ }^{\circ}\left(\right.$ Table $\left.^{\circ} 1\right),{ }^{\circ}$ corresponds ${ }^{\circ}$ to accuracies of $6.3,5.1$, and 0.06 ppm for the receptorligand complexes. This degree of mass accuracy allows the bound ligand mass to be determined to better than 0.2 Da. Although nowhere near sufficient for the assignment of a unique elemental composition to the ligand, this degree of mass accuracy allows chain length and degree of unsaturation (or cyclization) to be determined if the class of ligand being investigated is known (fatty acid) and is relevant in the testing of complex ligand mixtures such as a combinatorial library comprised of known components. It should be noted that in the best case (i.e., an average mass error of $0.002 \mathrm{Da}$ for linolenic acid) the observed mass error is only $7.3 \mathrm{ppm}$ of the ligand mass. 
In addition, nondenaturing ES mass spectrometry was used to show the binding of a novel synthetic agonist XCT0315908 to the RXR $\alpha$ LBD. In terms of holo-receptor peak intensity, receptor occupancy appears ${ }^{\circ}$ to ${ }^{\circ}{ }^{\circ}{ }^{\circ}$ slightly ${ }^{\circ}{ }^{\circ}$ ower ${ }^{\circ}$ than ${ }^{\circ}$ for $^{\circ} \mathrm{DHA}^{\circ}$ (cf. ${ }^{\circ}$ Figures ${ }^{\circ} 5 \mathrm{a}$ and $\left.^{\circ} 1 \mathrm{~b}\right) .{ }^{\circ} \mathrm{It}^{\circ}{ }^{\circ}$ is ${ }^{\circ}$ clear, ${ }^{\circ}$ however, ${ }^{\circ}$ that ${ }^{\circ}$ the ${ }^{\circ} \mathrm{XCT} 0315908^{\circ}$ is behaving like an RXR ligand because the relative intensity of the holo-RXR $\alpha$ peaks are far greater than for the $\mathrm{RXR} \alpha$ nonagonist $\mathrm{E}_{2^{\circ}}\left(\mathrm{cf}^{\circ}{ }^{\circ}\right.$ Figures $\left.{ }^{\circ} 5 \mathrm{a}^{\circ} \mathrm{and}^{\circ} 1 \mathrm{~d}\right) .{ }^{\circ}$ Binding ${ }^{\circ}$ of XCT0315908 within the ligand binding pocket (LBP) of RXR is likely given the overall structural similarity between LG268 (a high-affinity $\mathrm{RXR} \alpha$ agonist) and XCT0315908 ${ }^{\circ}$ (Figure $5 \mathrm{~b},{ }^{\circ} \mathrm{c}$ ), ${ }^{\text {ow }}$ where ${ }^{\circ}$ the ${ }^{\circ}$ anchoring ${ }^{\circ}$ of LG268 in the LBP is by ionic interaction between the carboxylic acid $^{\circ}$ group ${ }^{\circ}$ and $^{\circ} \mathrm{a}^{\circ}$ conserved ${ }^{\circ}$ arginine ${ }^{\circ}$ residue ${ }^{\circ}[29]$.

A final comment is required on the feasibility of the current methodology to observe ligand binding from a solution containing multiple closely related (in mass) potential ligands. Empirically, a holo-RXR peak involving single ligand binding can be expected to have a FWHM of $\sim 1.3 \mathrm{Da}$, while that of a holo-RXR peak corresponding to mixed binding of two similar affinity ligands differing in mass by 4 Da will have a FWHM of $\sim 1.6 \mathrm{Da}$. The exact width and center of the peak will depend on the relative affinity of the ligands and their exact mass. However, the observation of peak broadening will alert the investigator to the possibility of multiple ligand binding.

In conclusion, the results of the current study show that nondenaturing ES mass spectrometry can be used to determine the mass of binding ligands with sufficient accuracy to provide information on their structure.

\section{Acknowledgments}

The authors acknowledge the financial support from the Swedish Research Council (grant no. 03X-12551), the Swedish Strategic Science Foundation (TP), the Swedish Foundation for Medical Research (SSMF, JL), the foundation Lars Hiertas Minne (JL), and the UK Biotechnology and Biological Sciences Research Council (BBSRC grant no. BB/C515771/1). The freely given advice of Brian Green at Micromass, Manchester, UK, is warmly acknowledged.

\section{References}

1. Beynon, J. H. Qualitative Analysis of Organic Compounds by Mass Spectrometry. Nature 1954, 174, 735-737.

2. Beynon, J. H. Mass Spectrometry and its Applications to Organic Chemistry; Elsevier: Amsterdam, 1960.

3. Russell, D. H.; Edmondson, R. D. High-Resolution Mass Spectrometry and Accurate Mass Measurements with Emphasis on the Charachterization of Peptides and Proteins by Matrix-Assisted Laser Desorption/Ionization Time-of-flight Mass Spectrometry. J. Mass Spectrom. 1997, 32, 263-276.

4. McLafferty, F. W.; Turecek, F. Interpretation of Mass Spectra; 4th ed.; University Science Books: Mill Valley, CA, 1993.

5. McMurray, W. J.; Green, B. N.; Lipsky, S. R. Fast Scan High Resolution Mass Spectrometry. Operating Parameters and Its Tandem Use with Gas Chromatography. Anal. Chem. 1966, 38, 1194-1204.

6. D'Agostino, P. A.; Hancock, J. R.; Provost, L. R.; Semchuk, P. D.; Hodges, R. S. High Resolution Electrospray Mass
Spectrometry With a Magnetic Sector Instrument: Accurate Mass Measurement and Peptide Sequencing. Rapid Commun. Mass Spectrom. 1995, 9, 597-603.

7. Yang, Y.; Griffiths, W. J.; Nordling, M.; Nygren, J.; Moller, L.; Bergman, J.; Liepinsh, E.; Otting, G.; Gustafsson, J. A.; Rafter, J.; Sjovall, J. Ring Opening Of Benzo[a]pyrene in the GermFree Rat Is a Novel Pathway for Formation of Potentially Genotoxic Metabolites. Biochemistry 2000, 39, 15585-15591.

8. Wang, Y.; Johansson, J.; Griffiths, W. J. Characterisation of Variant Forms of Prophenin: Mechanistic Aspects of the Fragmentation of Proline-Rich Peptides. Rapid Commun. Mass Spectrom. 2000, 14, 2182-202.

9. Abraham-Nordling, M.; Gudmundsson, G. H.; Grunewald, J.; Agerberth, B.; Griffiths, W. J. Identification of a Potent Antibacterial Factor Isolated From Bronchoalveolar Lavage Fluid: Guanidine, $N$-[3-[(aminoiminomethyl)amino]propyl]- $N$-dodecyl-, a Potential Source of Error in the Analysis of Antibacterial Agents. Rapid Commun. Mass Spectrom. 2003, 17, 183-191.

10. Marshall, A. G.; Hendrickson, C. L.; Jackson, G. S. Fourier Transform Ion Cyclotron Resonance Mass Spectrometry: A Primer. Mass Spectrom. Rev. 1998, 17, 1-35.

11. Bahr, U.; Karas, M. Differentiation of "Isobaric" Peptides and Human Milk Oligosaccharides by Exact Mass Measurements Using Electrospray Ionization Orthogonal Time-Of-Flight Analysis. Rapid Commun. Mass Spectrom. 1999, 13, 1052-1058.

12. Wolff, J. C.; Eckers, C.; Sage, A. B.; Giles, K.; Bateman, R. Accurate Mass Liquid Chromatography/Mass Spectrometry on Quadrupole Orthogonal Acceleration Time-Of-Flight Mass Analyzers Using Switching Between Separate Sample and Reference Sprays. 2. Applications Using the Dual-Electrospray Ion Source. Anal. Chem. 2001, 73, 2605-2612.

13. Steen, H.; Mann, M. Analysis of Bromotryptophan and Hydroxyproline Modifications by High-Resolution, High-Accuracy Precursor Ion Scanning Utilizing Fragment Ions With Mass-Deficient Mass Tags. Anal. Chem. 2002, 74, 6230-6236.

14. Clauwaert, K.; Vande Casteele, S.; Sinnaeve, B.; Deforce, D.; Lambert, W.; Van Peteghem, C.; Van Bocxlaer, J. Exact Mass Measurement of Product Ions for the Structural Confirmation and Identification of Unknown Compounds Using a Quadrupole Time-Of-Flight Spectrometer: A Simplified Approach Using Combined Tandem Mass Spectrometric Functions. Rapid Commun. Mass Spectrom. 2003, 17, 1443-1448.

15. Charles, L.; Pepin, D.; Gonnet, F.; Tabet, J. C. Effects of Liquid Phase Composition on Salt Cluster Formation in Positive Ion Mode Electrospray Mass Spectrometry: Implications for Clustering Mechanism in Electrospray. J. Am. Soc. Mass Spectrom. 2001, 12, 1077-1084.

16. Morgan, R. P.; Beynon, J. H.; Bateman, R. H.; Green, B. N. The MM-ZAB-2F Double Focusing Mass Spectrometer and Mike Spectrometer. Int. J. Mass. Spectrom. Ion. Phys. 1978, 28, 171-191.

17. Rodgers, R. P.; Blumer, E. N.; Hendrickson, C. L.; Marshall, A. G. Stable Isotope Incorporation Triples the Upper Mass Limit for Determination of Elemental Composition by Accurate Mass Measurement. J. Am. Soc. Mass Spectrom. 2000, 11, 835-840.

18. Shi, S. D.; Hendrickson, C. L.; Marshall, A. G. Counting Individual Sulfur Atoms in a Protein by Ultrahigh-Resolution Fourier Transform Ion Cyclotron Resonance Mass Spectrometry: Experimental Resolution of Isotopic Fine Structure in Proteins. Proc. Natl. Acad. Sci. U.S.A. 1998, 95, 11532-11537.

19. Carr, S. A.; Burlingame, A. L.; Baldwin, M. A. The Meaning and Usage of the Terms Monoisotopic Mass, Average Mass, Mass Resolution, and Mass Accuracy for Measurements of Biological Molecules. In Mass Spectrometry in Biology and Medicine, Carr, S.; Burlingame, A.L.; Baldwin, M.A., Eds.; Humana Press: Totowa, NJ, 2000. 
20. Tyler, A. N.; Clayton, E.; Green, B. N. Exact Mass Measurement of Polar Organic Molecules at Low Resolution Using Electrospray Ionization and a Quadrupole Mass Spectrometer. Anal. Chem. 1996, 68, 3561-3569.

21. Mann, M.; Hendrickson, R. C.; Pandey, A. Analysis of Proteins and Proteomes By Mass Spectrometry. Annu. Rev. Biochem. 2001, 70, 437-473.

22. Rai, D. K.; Griffiths, W. J.; Landin, B.; Wild, B. J.; Alvelius, G.; Green, B. N. Accurate Mass Measurement by Electrospray Ionization Quadrupole Mass Spectrometry: Detection of Variants Differing by $<6$ Da from Normal in Human Hemoglobin Heterozygotes. Anal. Chem. 2003, 75, 1978-1982.

23. Steinmetz, A. C.; Renaud, J. P.; Moras, D. Binding of Ligands and Activation of Transcription by Nuclear Receptors. Annu. Rev. Biophys. Biomol. Struct. 2001, 30, 329-359.

24. Rocchi, S.; Picard, F.; Vamecq, J.; Gelman, L.; Potier, N.; Zeyer, D.; Dubuquoy, L.; Bac, P.; Champy, M. F.; Plunket, K. D.; Leesnitzer, L. M.; Blanchard, S. G.; Desreumaux, P.; Moras, D.; Renaud, J. P.; Auwerx, J. A Unique PPARgamma Ligand With Potent Insulin-Sensitizing Yet Weak Adipogenic Activity. Mol. Cell. 2001, 8, 737-747.

25. Potier, N.; Lamour, V.; Poterszman, A.; Thierry, J. C.; Moras, D.; Van Dorsselaer, A. Characterization of Crystal Content by ESI-MS and MALDI-MS. Acta Crystallogr D Biol Crystallogr 2000, 56, 1583-1590.

26. Greschik, H.; Wurtz, J. M.; Sanglier, S.; Bourguet, W.; van Dorsselaer, A.; Moras, D.; Renaud, J. P. Structural and Functional Evidence for Ligand-Independent Transcriptional Activation by the Estrogen-Related Receptor 3. Mol. Cell. 2002, 9, 303-313.

27. Lengqvist, J.; Griffiths, W. J.; Perlmann, T.; Sjövall, J. Detection of a Receptor-Ligand Non-Covalent Complex Using a Triple Quadrupole Mass Spectrometer. Rapid Commun. Mass Spectrom. 2002, 16, 2003-2006.

28. Lengqvist, J.; De Urquiza, A. M.; Bergman, A. C.; Wilson, T. M.; Sjovall, J.; Perlmann, T.; Griffiths, W. J. Polyunsaturated Fatty Acids Including Docosahexaenoic and Arachidonic Acid Bind to the Retinoid X Receptor Alpha Ligand Binding Domain. Mol. Cell. Proteomics 2004, 3, 692-703.

29. Egea, P. F.; Mitschler, A.; Moras, D. Molecular Recognition of Agonist Ligands by RXRs. Mol. Endocrinol. 2002, 16, 987-997.

30. Xu, H. E.; Lambert, M. H.; Montana, V. G.; Parks, D. J.; Blanchard, S. G.; Brown, P. J.; Sternbach, D. D.; Lehmann, J. M.; Wisely, G. B.; Willson, T.M.; Kliewer, S.A.; Milburn, M.V. Molecular Recognition of Fatty Acids by Peroxisome Proliferator-Activated Receptors. Mol. Cell. 1999, 3, 397-403.

31. Forman, B. M.; Ruan, B.; Chen, J.; Schroepfer, G. J. J.; Evans, R. M. The Orphan Nuclear Receptor LXRalpha Is Positively and Negatively Regulated by Distinct Products of Mevalonate Metabolism. Proc. Natl. Acad. Sci. U.S.A. 1997, 94, 10588-10593.

32. Claudel, T.; Leibowitz, M. D.; Fievet, C.; Tailleux, A.; Wagner, B.; Repa, J. J.; Torpier, G.; Lobaccaro, J. M.; Paterniti, J. R.; Mangelsdorf, D. J.; Heyman, R. A.; Auwerx, J. Reduction of Atherosclerosis in Apolipoprotein E Knockout Mice by Activation of the Retinoid X Receptor. Proc. Natl. Acad. Sci. U.S.A. 2001, 98, 2610-2615.

33. Wang, H.; Chen, J.; Hollister, K.; Sowers, L. C.; Forman, B. M. Endogenous Bile Acids Are Ligands for the Nuclear Receptor FXR/BAR. Mol. Cell. 1999, 3, 543-553.

34. Parks, D. J.; Blanchard, S. G.; Bledsoe, R. K.; Chandra, G.; Consler, T. G.; Kliewer, S. A.; Stimmel, J. B.; Willson, T. M.;
Zavacki, A. M.; Moore, D. D.; Lehmann, J.M. Bile Acids: Natural Ligands for an Orphan Nuclear Receptor. Science 1999, 284, 1365-1368.

35. Radominska-Pandya, A.; Chen, G. Photoaffinity Labeling of Human Retinoid X Receptor Beta (RXRbeta) With 9-cis-Retinoic Acid: Identification of Phytanic Acid, Docosahexaenoic Acid, and Lithocholic Acid as Ligands for RXRbeta. Biochemistry 2002, 41, 4883-4890.

36. de Urquiza, A. M.; Liu, S.; Sjoberg, M.; Zetterstrom, R. H.; Griffiths, W.; Sjövall, J.; Perlmann, T. Docosahexaenoic Acid, a Ligand for the Retinoid X Receptor in Mouse Brain. Science 2000, 290, 2140-2144.

37. Goldstein, J. T.; Dobrzyn, A.; Clagett-Dame, M.; Pike, J. W.; DeLuca, H.F. Isolation and Characterization of Unsaturated Fatty Acids as Natural Ligands for the Retinoid-X Receptor. Arch. Biochem. Biophys. 2003, 420, 185-193.

38. Giguere, V. Orphan Nuclear Receptors: From Gene to Function. Endocr. Rev. 1999, 20, 689-725.

39. Potier, N.; Billas, I. M.; Steinmetz, A.; Schaeffer, C.; van Dorsselaer, A.; Moras, D.; Renaud, J. P. Using Nondenaturing Mass Spectrometry to Detect Fortuitous Ligands in Orphan Nuclear Receptors. Protein Sci. 2003, 12, 725-733.

40. Wallen-Mackenzie, A.; Mata de Urquiza, A.; Petersson, S.; Rodriguez, F. J.; Friling, S.; Wagner, J.; Ordentlich, P.; Lengqvist, J.; Heyman, R. A.; Arenas, E.; Perlmann, T. Nurr1RXR Heterodimers Mediate RXR Ligand-Induced Signaling in Neuronal Cells. Genes Dev. 2003, 17, 3036-3047.

41. Egea, P. F.; Rochel, N.; Birck, C.; Vachette, P.; Timmins, P. A.; Moras, D. Effects of Ligand Binding on the Association Properties and Conformation in Solution of Retinoic Acid Receptors RXR and RAR. J. Mol. Biol. 2001, 307, 557-576.

42. Chen, Z. P.; Iyer, J.; Bourguet, W.; Held, P.; Mioskowski, C.; Lebeau, L.; Noy, N.; Chambon, P.; Gronemeyer, H. Ligandand DNA-Induced Dissociation of RXR Tetramers. J. Mol. Biol. 1998, 275, 55-65.

43. Kersten, S.; Kelleher, D.; Chambon, P.; Gronemeyer, H.; Noy, N. Retinoid X Receptor Alpha Forms Tetramers in Solution. Proc. Natl. Acad. Sci. U.S.A. 1995, 92, 8645-8649.

44. Tahallah, N.; Pinkse, M.; Maier, C. S.; Heck, A. J. The effect of the Source Pressure on the Abundance of Ions of Noncovalent Protein Assemblies in an Electrospray Ionization Orthogonal Time-Of-Flight Instrument. Rapid Commun. Mass Spectrom. 2001, 15, 596-601.

45. Ferrige, A. G.; Seddon, M. J.; Green, B. N.; Jarvis, S. A.; Skilling, J. Disentangling Electrospray Spectra With Maximum Entropy. Rapid Commun. Mass. Spectrom. 1992, 6, 707-711.

46. Green, B. N.; Vinogradov, S.N. An Electrospray Ionization Mass Spectrometric Study of the Subunit Structure of the Giant Hemoglobin From the Leech Nephelopsis oscura. J. Am. Soc. Mass. Spectrom. 2004, 15, 22-27.

47. De Laeter, R.; Heumann, K. G.; Barber, I. L., et al. Pure Appl. Chem. 1991, 63, 975-990.

48. Willson, T. M.; Jones, S.A.; Moore, J. T.; Kliewer, S. A. Chemical Genomics: Functional Analysis of Orphan Nuclear Receptors in the Regulation of Bile Acid Metabolism. Med. Res. Rev. 2001, 21, 513-522.

49. Loo, J. A. Studying Noncovalent Protein Complexes by Electrospray Ionization Mass Spectrometry. Mass. Spectrom. Rev. $1997,16,1-23$ 